Available online at

INSECTA

Integrative Science Education and Teaching Activity Journal

Journal homepage : https://jurnal.iainponorogo.ac.id/index.php/insecta

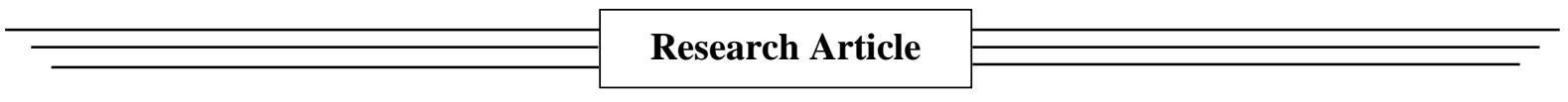

\title{
Application of Phet Simulation to Electrical Circuits Material in Online Learning
}

\author{
Nufus Choirum Masruroh ${ }^{1 *}$, Amelya Vivianti ${ }^{2}$, Putri Maulida Anggraeni ${ }^{3}$, \\ Siti Nailil Waroh ${ }^{4}$, Nur Wakhidah ${ }^{5}$ \\ ${ }^{1}$ UIN Sunan Ampel Surabaya, Surabaya, Indonesia \\ ${ }^{2}$ UIN Sunan Ampel Surabaya, Surabaya, Indonesia \\ ${ }^{3}$ UIN Sunan Ampel Surabaya, Surabaya, Indonesia \\ ${ }^{4}$ MIN 2 Sidoarjo, Sidoarjo, Indonesia \\ ${ }^{5}$ UIN Sunan Ampel Surabaya, Surabaya, Indonesia \\ * Corresponding Address: nufusuinsa@gmail.com
}

\section{Article Info}

Article history:

Received: October 1, 2020

Accepted: October 23, 2020

Published: November 27, 2020

\section{Keywords:}

Online Learning,

PhET Simulation Media,

Electrical Circuits

\begin{abstract}
This study aims to determine the application of learning electrical materials online using the PhET (Physics Education and Technology) simulation media for grade VI students. This quantitative descriptive study illustrates how the PhET simulation media is used in learning to cognitive learning outcomes. Sampling using purposive sampling technique as many as 10 students of MIN 2 Sidoarjo. Data collection techniques were carried out using questionnaires and tests which were sent to students via google form. The student's score is compared to the school's KKM score and the percentage is calculated. The results showed that (i) $80 \%$ of students scored above 75 with an average of 85,4 and (ii) $91 \%$ of students responded positively to using this application.
\end{abstract}

(C) 2020 Tadris Ilmu Pengetahuan Alam Department, IAIN Ponorogo, Indonesia.

\section{INTRODUCTION}

Education is one of the keys to success in building the Nation of Indonesia to be more advanced. The development will continue as tangible evidence of the development of a country. To participate in carrying out development, each individual is expected to be able to improve its quality through learning which is one aspect of education (Pujiyono et al., 2016). Currently, the study is carried out online by the policy of the Ministry of Education in Circular Letter number 4 of 2020 due to the Covid-19 pandemic in Indonesia beginning in mid-March 2020. This is intended so as not to prevent the widespread of the virus in students and school communities.

Online learning is distance learning through virtual activities that require an internet network and can be accessed anywhere to bring up different types of learning interactions (Firman \& Rahayu, 2020). This learning is considered one of the solutions used as a material greeting from teachers to students. This form of online learning is conventional learning that is delivered in a media format and relies on the internet network. Connecting students with learning resources will occur separately or far away but still interact with each other, 
communicate, and collaborate. All teaching activities that are usually carried out in schools, can now only be done at home without a meeting in person between students and teachers. One such activity is a practicum. Students can no longer experience practical activities in the classroom or the school laboratory.

Practicum is an alternative activity that encourages students to connect their conceptual understanding so that they can equip themselves to better understand the theory. Learning using practicum will encourage students to be more active and increase success in teaching and learning activities (Baeti et al., 2014). Students will also benefit from practical activities, including 1) They have the opportunity to integrate and apply their knowledge and skills, 2) Be able to prove scientifically, and 3) Students appreciate their existing skills and science (Nisa, 2017). Practicum activities are an important part of science education. It is intended to achieve the objectives of science education, namely for the development of understanding, knowledge, and analytical capabilities that students have in the surrounding environment. There are several reasons for the importance of practicum in science learning, namely 1) As a supporting subject matter, 2) Able to generate students' motivation to learn IPA, 3) The development of basic skills in conducting experiments, as well as 4) As a means of learning with a scientific approach (Baeti et al., 2014).

IPA or Natural Science is a science that discusses the events and symptoms of the universe and its contents objectively and rationally (Muakhirin, 2014). Electrical circuits as IPA learning materials in grade VI require practicum activities to help students understand concepts in real-time. A series consisting of mixtures, series, and parallels is material that students find difficult to understand. According to the revealed by grade VI-A teacher MIN 2 Sidoarjo, that during online learning almost $70 \%$ of students with grades are below KKM (Minimum Level Criteria) on electrical circuit material. Difficulties experienced by students can also occur because, during the learning process, the concept of electricity is only conveyed in the form of information without any experiments or experiments that cause students to experience abstract concepts and not the maximum results of learning (Anam, 2013). Therefore, media assistance is needed in its implementation. Teachers are required to master technology, information, and communication to solve problems in presenting learning online to students. One of the factors that teachers struggle with when teaching science subjects is the lack of knowledge about IPA learning media which causes students' experience in the acquisition of science process skills to be reduced (Wakhidah, 2016).

Learning media is something that can facilitate teachers in delivering learning materials to students both technical and physical to achieve learning goals (Adam, 2015). The need for media for students to not only think abstractly, but be able to observe, experience, and feel material concepts in real-time. Media is one aspect of learning that utilizes digital technology to support the process of learning to teach online. Learning media that used to be objects, people, the environment, or anything that is an intermediary in the delivery of materials, can currently only be presented by teachers visually. Through online learning media, practicum, which was originally implemented in a classroom or school laboratory, can now be done with the help of virtual simulation media.

Virtual simulation media is a medium or series of programs that can help students to conduct experiments by visualizing abstract phenomena into experiments conducted in a virtual or online way. The media can assist in the development of skills as well as the improvement of learning activities in problem-solving activities (Sutarno et al., 2017). The benefits obtained from the use of virtual simulation media are that it can improve the quality of experiments, where in the event of doubts about the results of the experiment it will be possible to be repeated; its use is more economical i.e. it does not require space, tools, and materials as in real laboratories; effective in remote use; guaranteed safety and security as there is no need to come into direct contact with real laboratory tools and materials; can 
overcome time constraints, where students can use them at any time; and certainly able to improve the effectiveness of learning because it can help students understand the concept of materials.

Physics Education Technology or PhET is a virtual simulation medium that is useful for students to help facilitate the understanding of concepts and conduct practices/simulations independently of series, parallel, and mixed electrical circuits. Sinulingga et al. (2016) explains that PhET is a research-based interactive simulation that can be used in IPA experiments and is affordable by technology and flexible. PhET simulation media was developed by the University of Colorado science team in the United States. PhET is considered suitable to be applied to students because of its ease of use that presents virtual simulations as needed during this kind of online learning period. This simulation media is not paid so it is free to use by anyone without having to have an account first. PhET can be used online by directly running the simulation or offline by downloading first on the http://phet.colorado.edu then installing it on your mobile phone or windows. PhET size is not too large, so it does not consume much quota or consume internal memory. In its use, there are rarely obstacles such as long loading, jamming (unusable), or malfunctioning features in PhET.

PhET's advantage is that it can build a mindset of student constructivism, where their initial knowledge can be combined with virtual findings based on simulations conducted. Also, PhET becomes a learning approach that involves student interaction and makes teaching-learning activities more enjoyable because students can play while learning by visualizing the concept of IPA into model form (Sari et al., 2013). The design principles used in building PhET simulation media are to provide useful simulations for all educational situations and are utilized flexibly, making the invisible visible, the provision of interactivity, the use of connections in the real world, the accompanying representations (such as numbers, movement of objects, graphs, and so on), as well as the implicit guidance given to users (Sylviani, et al., 2020).

During online learning, the application of PhET simulation media utilized for virtual lab activities has functions such as improving knowledge/concepts, bringing up scientific attitudes, and helping students carry out activities based on scientific methods (including observing activities, formulating problems, compiling hypotheses, conducting experiments, analyzing data, making conclusions, and communicating) (Alfarizi et al., 2020). Learning that utilizes PhET can help students to collect more complete data so that they can independently conclude the results of experiments conducted. This is because PhET simulation media is designed to ignore anything that can affect the observation results. Unlike learning that uses laboratory equipment in real-time. Students will experience difficulties during the data collection process, as it depends on the level of precision of the tool as well as the conditions for obtaining the necessary data. They will also require deepening analysis to get close to the expected concept.

PhET simulation provides tools and materials that make it easier for users to conduct and develop experiments online. Users seem to use actual practical tools in the laboratory. PhET provides students with the opportunity to improve their critical thinking skills through experiments conducted by creating a wide range of electrical circuit designs. This is by the purpose of science education which is to develop critical thinking skills. These skills need to be taught during learning because they are needed in the face of the 21 st century (Wakhidah, 2018). Through PhET, students will experience a high level of thought process that is useful for solving problems, developing experiments, and making conclusions (Rahmawati, 2019). Thus, it is expected that students can explain the concept of experiments they are doing as well as find a new concept. 
This study raises the issue (1) how successful the application of online learning of electrical circuit materials using PhET (Physics Education and Technology) simulation media and (2) how effective the application of online learning is using PhET simulation media (Physics Education and Technology) in helping to understand the electrical circuit materials of grade VI students. The purpose of this study is (1) to know how much success rate of online learning of electrical circuit materials using PhET (Physics Education and Technology) simulation media and (2) know the effectiveness of the application of online learning using PhET simulation media (Physics Education and Technology) in helping to understand the electrical circuit materials of grade VI students.

The results of previous research by Pujiyono et al. (2016) revealed that the use of PhET simulation media in physics learning is considered effective to help students in understanding electrical field vector materials as well as motivating them to study Physics. Also, the results of the survey conducted by Alfarizi et al. (2020) show that PhET learning media based virtual lab in online lectures of static electrical materials has the attractiveness among them is the design of good view, material content, and content of interesting experiments and according to the needs of students. Research by Yusran et al. (2017) yielded the conclusion that PhET simulations are effective in remediation of misconceptions that occur in students in direct current electrical circuit matter. Fithriani et al. (2016) also gave the results of his research, namely PhET simulation media can improve students' critical thinking skills. The results of Dewa et al. (2020) state that online learning with the help of virtual laboratories influences the cognitive learning outcomes of students of grade X MIPA 1.

The results that have been presented by previous researchers form a statement that $\mathrm{PhET}$ is effective in helping users understand material concepts, able to provide learning motivation, can improve critical thinking skills, can prevent material misconceptions, has interestingness and according to the needs of the user, and influences the learning outcomes. Previous studies have been the basis for authors in carrying out research. The difference is that the authors conducted research on the effectiveness of the application of PhET simulation media in electrical circuit materials during online learning for grade VI elementary/MI students.

\section{METHODS}

This research method is a quantitative descriptive method that describes or explains a situation that is examined based on the results of calculations in the form of numbers and qualitative data that is guessed (Rosliani, 2017). The techniques used in analyzing data are descriptive and supported by literature studies. Sampling using a purposive sample technique is only sample members that meet the elements of research based on the consideration of researchers (Hanifah \& Admoko, 2019). Students who have internet facilities and can access google meet as well as PhET simulation media during learning are the samples selected in this study. The sample was 10 students from grade VI-A of the odd semester of the 2020/2021 school year. This research was conducted from September 14 to October 06, 2020, at MIN 2 Sidoarjo.

To determine the effectiveness of the application of PhET simulation media during online learning of electrical circuit materials, data is collected using questionnaires and tests distributed to students through a google form. Questionnaires serve to measure students' responses or opinions to feelings of pleasure, attraction, attraction, and ease of use of PhET simulation media for electrical circuit materials. The results of the student response questionnaire were collected and then calculated how many students responded positively or otherwise, after which it was followed by analysis. The application of PhET simulation media in learning is said to be effective with the target if students give a positive response of at least 
$70 \%$ of the sample count. The percentage effectiveness of PhET (X) simulation media is obtained by:

$$
\mathrm{X}=\frac{\text { Number of students with positive responses }}{\text { Total number of students }} \times 100 \%
$$

While the question test serves to measure students' ability in electrical circuit materials after the implementation of online learning. Evaluation test results are analyzed after it is known the grades of each student and the percentage of the number of students showing grades above and below the provisions. The question given is 10 items with details of 7 multiple options and 3 essay questions. Learning is said to be successful with a target of at least $70 \%$ of the number of students getting a minimum completed grade (KKM) of 75 . The percentage of student success $(\mathrm{P})$ can be obtained through the following means:

$$
\mathrm{P}=\frac{\text { Number of students who have grades } \geq 75}{\text { Total number of students }} \times 100 \%
$$

\section{RESULTS AND DISCUSSIONS}

After conducting online learning with the application of PhET simulation media in electrical circuit material, descriptive analysis of the results of the evaluation and response tests of students. These results are then described to determine the success rate and effectiveness of the application of PhET simulation media.

\section{Evaluation Test Analysis}

To know the understanding of the electrical circuit, students are given the question of evaluation test with the help of PhET simulation media after online learning activities are carried out. Here are the results of the student evaluation test.

\begin{tabular}{|c|c|c|}
\hline No. & Name & Value \\
\hline 1. & Alfatunisa & 100 \\
\hline 2. & Fachri & 48 \\
\hline 3. & Imamir & 73 \\
\hline 4. & Layliya & 100 \\
\hline 5. & Kholilur & 80 \\
\hline 6. & Naufal & 85 \\
\hline 7. & Nazwa & 85 \\
\hline 8. & Prameswari & 83 \\
\hline 9. & Retno & 100 \\
\hline 10. & Uqoilah & 100 \\
\hline \multicolumn{2}{|c|}{ Average } & 85,4 \\
\hline
\end{tabular}

Table 1. Student evaluation test results

From the evaluation results, it is known that students who managed to get a $\geq$ score of 75 were 8 , and students with a $\leq$ score of 75 as many as 2 people with the highest score of 100 and the lowest score of 48 . So it can be categorized that $80 \%$ of students have met the minimum completed criteria (KKM) with an overall average score of 85,4. Based on the results of the analysis, the results of the study of students in good categories and showed that PhET simulation media was successful to be applied in the online learning of grade VI electrical circuit materials. When conducting an evidentiary experiment on a problem, the evidence from the results of the experiment can be shared with PhET simulation media. This is certainly very helpful in boosting students' learning outcomes. By Saregar's explanation (2016), his findings in Nur's research (2013) showed better student learning outcomes when using PhET simulation media compared to without using them. The difference in learning 
outcomes is due to PhET simulation media being able to create online learning that attracts students and they not only imagine concepts abstractly but can see them in person.

There is a presumption that a student's success in the learning process is seen from the results of learning, so choosing media is very important for the teacher. The selection of the right learning media will help improve students' learning outcomes. When using PhET, students will raise questions that can help them in making hypotheses to the discovery of concepts that are associated with daily life and end with making conclusions. In addition to improving understanding, PhET also serves to facilitate the interpretation of data, present data interestingly, and compress the information obtained.

\section{Questionnaire Analysis}

Students respond to a questionnaire sheet about the use of PhET simulation media during online learning of electrical circuit materials after working on evaluation tests. There are 3 questions and 7 statements in the questionnaire, including:

1. Can you understand electrical circuit material after using the PhET application? Give me your reason!

2. Are there any difficulties you experience when using the PhET application? Give me your reason!

3. Can use the PhET application make it easier for you to design electrical circuits? Give me your reason!

4. PhET simulation media is useful for learning electrical circuits.

5. In my opinion, PhET simulation media in the learning of electrical circuit materials is boring.

6. Learning using PhET simulation media made me more skilled in designing electrical circuits.

7. PhET simulation media makes it difficult for me to solve electrical circuit problems.

8. PhET simulation media encourages me to discover new ideas.

9. Learning electrical circuits using PhET simulation media made me better understand the material.

10. Learning electrical circuits using PhET simulation media makes material memorable.

Based on the results of the questionnaire that has been filled by students, it is known in the first question as many as $70 \%$ of students responded that after using PhET simulation media they were able to understand the electrical circuit material. PhET has a role that can help learning become easier for students to understand. Through basic understanding connected to real life, PhET can assist students in improving learning activities and outcomes (Lidiana et al., 2018). PhET as a virtual starting media can make teaching-learning activities to the maximum with the cognitive interaction between subjects, students, and materials. Students' learning interests will increase if they are active in the learning process. So students are more likely to continue to pay attention to the subject matter submitted by the teacher, have an interest in the material, and will remember or remember the activities they did.

PhET simulation media utilized as a virtual laboratory can help students understand the concept of electrical circuit material, thus students not only acquire practical knowledge about the circuit. Students are allowed to really study the material at all times and can be repeated until they fully understand the concept. Also, they will experience scientific activities in understanding the symptoms of nature with the process of self-learning. Students will indirectly imitate the way scientists work in the process of finding concepts, facts, laws, and principles.

In a second question, $70 \%$ of students revealed that they felt no difficulty in using PhET. Comparable to Alfarizi's research (2020) which suggests that components in PhET simulation media are easy to understand by users, to foster a sense of interest and passion to 
conduct experiments. All components in PhET each have a name description, such as batteries, lights, cables, and so on. So students don't feel confused when using it. The variety of language options provided by PhET can also make it easier for users to create various experiments. Students who do not really understand the use of English can change it to Indonesian.

$\mathrm{PhET}$, which is an interactive medium, can be used by students independently or with the help of teacher explanations. Students can use PhET media automatically or by trying it out themselves. They can also choose an environment that suits their own way of learning. PhET visual display is suitable for children at the elementary school level. This media can reduce even the level of student addiction to games that are often played because PhET also resembles a game to attract students to keep trying it. Thus, students who initially only liked the game will also like to learn.

As for question number three, as many as $90 \%$ of students feel PhET media can facilitate them in designing electrical circuits. The features made to resemble the original provide an experience for students as if they were designing a real electric circuit. Students also do not have to worry about doing simulations. They can freely use features in PhET simulation media without thinking about tools and materials that have high precision and are dangerous and at risk of workplace accidents such as in real laboratories. Therefore, students will enjoy their experiments more.

In designing the electrical circuit, PhET will simulate an image of the movement of the current in a circuit, where the current cannot be seen by the naked eye on the actual electronic components. It will later help students in making electricity circuits in real-time. They will know that in the electrical circuit of the series if one of the lights is disconnected, then the other lamp is extinguished. Because the cables are arranged in parallel, so that if one of the lights is disconnected then the current flowing will also stop. In contrast to parallel sequences arranged in a row. When one of the lights is disconnected, the other lights will not go out. Because the flowing electric current can pass through other cables. The simulation will make it very easy for students to understand and create electrical circuits.

The percentage of students' responses to questions 1 to 3 shows that PhET simulation media is considered effective in making it easier for students to understand materials and create electrical circuits independently. This is in accordance with previous research by Pujiyono et al. (2016) on the effectiveness of PhET simulation media that has been discussed before.

Table 2. List of questionnaire results

\begin{tabular}{clcccccccc}
\hline \multirow{2}{*}{ No. } & \multirow{2}{*}{ Student Name } & \multicolumn{8}{c}{ Question No. } \\
\cline { 2 - 8 } & & $\mathbf{4}$ & $\mathbf{5}$ & $\mathbf{6}$ & $\mathbf{7}$ & $\mathbf{8}$ & $\mathbf{9}$ & $\mathbf{1 0}$ \\
\hline 1. & Alfatunisa & A & D & A & D & A & A & A \\
2. & Fachri & SA & D & SA & D & SA & SA & A \\
3. & Imamir & SA & SD & SA & SD & SA & SA & SA \\
4. & Layliya & SA & SD & SA & SD & SA & SA & SA \\
5. & Kholilur & A & D & A & D & A & A & A \\
6. & Naufal & A & A & A & A & SA & A & A \\
7. & Nazwa & SA & SD & SA & SD & SA & SA & SA \\
8. & Prameswari & A & D & A & D & A & A & A \\
9. & Retno & SA & D & SA & D & A & SA & SA \\
10. & Uqoilah & SA & SD & SA & SD & A & SA & A \\
\hline Description: & & & & & & & \\
SA $=$ Strongly Agree & & & & & & & \\
A $=$ Agree & & & & & & & \\
D $=$ Disagree & & & & & & & \\
SD $=$ Strongly Disagree & & & & & &
\end{tabular}




\begin{tabular}{llllllll}
\hline $\begin{array}{l}\text { Number of Strongly } \\
\text { Agree Answers }\end{array}$ & 6 & 0 & 6 & 0 & 5 & 6 & 4 \\
$\begin{array}{l}\text { Number of Agree } \\
\text { Answers }\end{array}$ & 4 & 1 & 4 & 1 & 5 & 4 & 6 \\
$\begin{array}{l}\text { Number of Disagree } \\
\text { Answers }\end{array}$ & 0 & 5 & 0 & 5 & 0 & 0 & 0 \\
$\begin{array}{l}\text { Number of Strongly } \\
\text { Disagree Answers }\end{array}$ & 0 & 4 & 0 & 4 & 0 & 0 & 0 \\
\hline
\end{tabular}

(Source: Personal Documents, 2020)

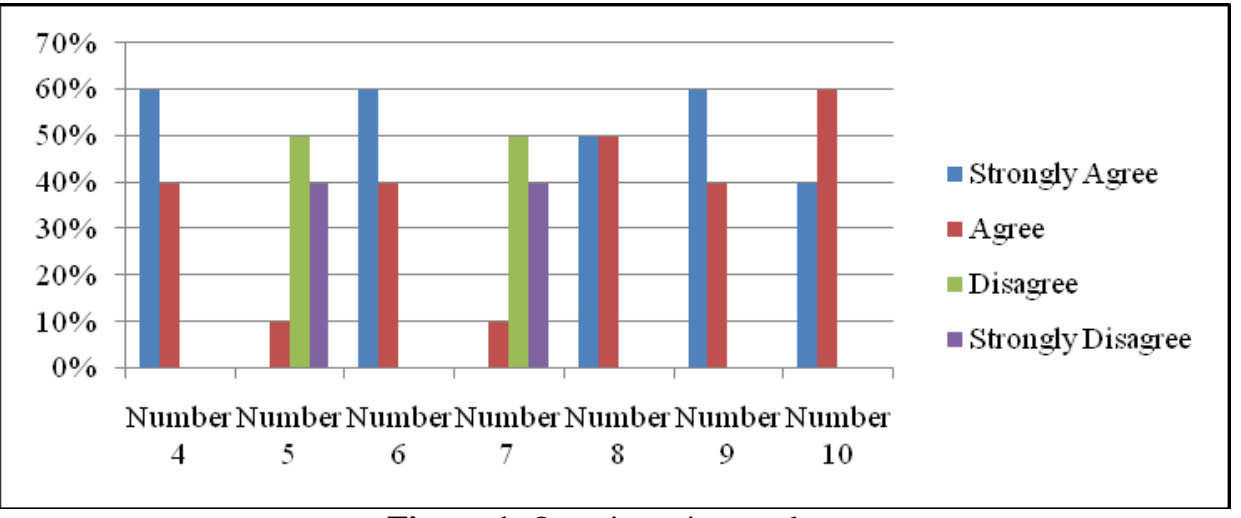

Figure 1. Questionnaire result percentage

(Source: Personal Documents, 2020)

In online learning, teachers often have difficulty in instilling concepts in students due to space limitations. PhET simulation media is useful in helping to solve the problem through the design of electrical circuits that can be easily applied to students. Through PhET students are able to understand the material and create electrical circuits independently. $60 \%$ of students strongly agree and $40 \%$ of students agree on statement number 4 . It showed $100 \%$ of students showed a positive response to the benefits of PhET media.

Among the media benefits of PhET for an electrical circuit, materials are reducing misconceptions in students to series and parallel circuits. Students sometimes still feel confused as to which includes parallel series and which includes series. Learning electrical circuit materials conducted only by lecture method without using experiments or experiments in them, will make students accept concepts abstractly so often they mistakenly assume the series is a parallel series or vice versa. To change the mindset that has been ingrained in students towards the concept of electrical circuits is not easy. Therefore, it takes a simulation medium that can clearly describe the concept of electrical circuits in order to straighten out the thinking of the wrong students beforehand. Through the use of PhET, students will be very helpful to understand the differences between the two series. Prevention of misconceptions is necessary for learning, as it will have an impact on students' learning outcomes.

Learning using PhET is able to develop students' creations in making various electrical circuit designs. Students design their own circuits to be created by assembling the components that have been provided. For students, it's like a game and makes learning not boring. Students can also repeat their experiments without any restrictions on how many experiments they have. Of the questionnaire results, it is known that as many as $50 \%$ of students voted to disagree, $40 \%$ of students responded strongly to disagree, and the rest voted to agree on statement number 5. A large number of presents with a positive response proves that $\mathrm{PhET}$ is effectively applied to the learning of electrical circuit materials.

Series, parallel, and mixed electric circuits have a wide variety of design firms. Just like the nets on waking up space in math subjects. Series, parallel, and mixed electrical 
circuits can also be changed the position of the lamp, the number of batteries used, and the number of cables as an electric current delivery. But the conversion still conforms to the criteria of the order of each series. Series are arranged in parallel, parallel sequences are arranged in a row, and mixed sequences are arranged in two ways i.e. parallel and in line. Students can develop creations to design electrical circuits to their liking by using PhET simulation media. Students can also learn the mistakes in designing electrical circuits because PhET can make simulated lights go out or catch fire if the electric current is not connected properly.

Statement number 6 shows a positive response as many as $60 \%$ of students voted strongly and $40 \%$ of students voted to agree. Thus it can be said that students become more skilled in designing electrical circuits when performing virtual simulations through PhET application. The display of the components is the same as the original, supporting students' ability to apply them to the electrical circuit in real-time. In addition, in its use, PhET simulation media has a considerable influence on the psychomotor skills that students have. They will be motivated if learning can apply the knowledge obtained by using PhET (Prihatiningtyas et al., 2013).

PhET simulation media in its application helps students understand the concept of materials. That understanding is gained through experiments that actively engage students in building knowledge. Through that knowledge, students will be easier in solving problems related to electrical circuit materials both in the form of tasks and in daily life in real-time. When conducting problem-solving activities with the help of PhET, students will get quick feedback from the simulation media about the effect of the changes they have made. So students don't have to take long to get results from solving an issue.

After conducting simulations on PhET media, students will self-memorize how to design electrical circuits in both series, parallel, and mixed. They will know the functions of electrical components such as batteries, cables, lights, switches, and so on. Students no longer need to see video views on youtube on how to create electrical circuits, because they already know design mistakes that should not be made for the lights to turn on properly. PhET simulation media can also help teachers to know the results of students' learning during online learning by providing evaluation test questions that require students to access PhET pages to design electrical circuits independently, whether series, parallel or mixed. Then the student simulation results are screened and sent to a google drive that has previously been provided by the teacher along with the test question. Teachers can evaluate how the design is made by students, whether or not the circuit is neat, whether the lights can turn on properly or not, and how students connect the circuits so that the lights can be lit.

As seen from the questionnaire results as many as 50\% of students answered disagreeing, $40 \%$ strongly disagreed, and $10 \%$ voted to agree to statement number 7 . This indicates that most students have no difficulty in solving problems after using PhET media. The exploration of simulations, assisting students in answering scientific questions, and conducting investigations into causal relationships. PhET's design principles as an interactive medium support this through the provision of easy-to-use tools or tools. One of the clicks and drag that works so that users can interact with the features in PhET simulation media. These interactions can occur by entering data, sliding objects, and pressing buttons.

The ease gained from PhET is time efficiency. Usually in experiments conducted in the laboratory will take a considerable time due to the limitations of tools and materials or the use of tools that take time to obtain results from research. Different when using PhET simulation media. A fast and easy process that is accessible to all students will save time in experimenting. PhET also provides convenience for students and teachers in avoiding the need for expensive or hard-to-obtain tools and materials. Only by mobile phone or computer, that can be used by anyone, anywhere, and anytime. 
In IPA learning, the use of PhET simulation media is a new thing felt by students, because in the previous electrical series material learning students were directly guided in creating the circuit. From the questionnaire results seen as many as 50\% of students with answers strongly agreed and $50 \%$ of students agreed on statement number 8 . It shows a fairly high level of student interest in the use of PhET simulation media. There is an interesting look that makes students enjoy the learning process and want to try to operate PhET to bring new ideas for them (Alfarizi et al., 2020). The emergence of the new idea proves PhET can improve students' critical thinking skills. Critical thinking skills are essential to train students in solving IPA problems and ensure learning success. Students get the opportunity to learn through discoveries by investigating the evidence, logic, and assumptions of ideas that others have. The ability that is this reflective way of thinking has a fundamental purpose in decisionmaking towards what students do.

Statement number 9 shows as many as $60 \%$ of students strongly agree and another $40 \%$ of students answering agree. It proves that the application of PhET simulation media in learning makes the material easier to understand and accept by students. Understanding is an act to understand an abstract idea or design that is done to classify an event or object. This is in Pujiyono's opinion, et al (2016) which states that applying to learn using PhET simulation media can help the understanding of the subject matter. Students with a good understanding will reduce the process of repetition of materials and certainly support their learning outcomes.

At the time of online learning, students must be given an in-depth explanation of the material taught so that they actually capture the concept of the material they want to provide. That's because students don't meet face-to-face with teachers. They cannot ask teachers directly what material is not understood or poorly understood. Teachers must select and create materials to the maximum extent, so as not to misconceptions when students study them (Rigianti, 2020). Sometimes some students will understand the material when seeing and hearing firsthand what the teacher describes. The learning style is based on each student's ability to absorb and process information (Bire et al., 2014). Meanwhile, students should be required to actively study independently and undergo experiments or experiments given by teachers for them to find material concepts by themselves. Therefore, the role of PhET simulation media is very helpful in the process of understanding students.

Learning electrical circuits through PhET simulation media helps students to more easily remember material concepts. They will remember the shape and arrangement of the circuit because it has managed to create an electric circuit independently. As seen from the questionnaire results as many as $40 \%$ of students strongly disagreed and $60 \%$ of other students voted to agree on statement number 10 stating electrical circuit material is memorable using the help of PhET. Electrical circuits are abstract materials for students if only given theory without experimentation. Explanations that do not display the original form will make students quickly forget and do not remember the concept that has been given. The different forms of electrical circuits ranging from series, parallels, and mixtures require students to know each of the differences between the three series. Therefore, the need to use PhET simulation media during online learning will make it easier for students to remember the concepts of each series.

The results of the analysis of questionnaire responses filled by students showed an average percentage of $91 \%$ of the number of students who responded positively to the application of PhET simulation media. Thus, PhET simulation media is considered effective in the online learning of grade VI electrical circuit materials.

INSECTA Volume 1 Number 2, 2020 | p-ISSN 2722-8509 | e-ISSN 2722-8495

Copyright (C) 2020 Nufus Choirum Masruroh, et. al. 


\section{CONCLUSION}

The conclusions obtained from the above research show that in its application to the online learning of grade VI electrical circuit materials, PhET simulation media was considered successful and effective. This is reviewed from the evaluation test results as $80 \%$ of students have met the minimum completed criteria score (KKM) 75 with an overall average score of 85,4 . The result exceeds the specified target. Also, the results of the analysis of questionnaire responses filled by students showed a percentage of $91 \%$ of the number of students who responded positively to PhET simulation media. So that the results obtained exceeded the expected target.

It is important for teachers when teaching to select and use interactive learning media so that students can easily and quickly understand the material and feel good. Therefore, PhET simulation media can be utilized by teachers for further science learning and does not stop until the electrical circuit material only. Also, there needs to be further research going forward with a larger and diverse sample/population so that the results of the study apply in a wider scope.

\section{REFERENCES}

Adam, S. \& Syastra, M.T. (2015). Pemanfaatan Media Pembelajaran Berbasis Teknologi Informasi Bagi Siswa Kelas X SMA Ananda Batam. CBIS Journal, 3(2), 78-90.

Anam, R.S. (2013). Pengaruh Penerapan Metode Eksperimen Nyata, Virtual, dan Gabungan dalam Pembelajaran IPA Berbasis Inkuiri Terhadap Pencapaian Kemampuan Kognitif dan Keterampilan Proses Sains Siswa SD, Bandung: Tesis Pendidikan Dasar Sekolah Pascasarjana Universitas Pendidikan Indonesia.

Alfarizi K., Rivo, Rifa'i, M., Ricky, \& Fajar, D. M. (2020). Analisis Kemenarikan Media Pembelajaran PhET Berbasis Virtual Lab Pada Materi Listrik Statis Selama Perkuliahan Daring Ditinjau Dari Perspektif Mahasiswa. Vektor: Jurnal Pendidikan IPA, 1(1), 19-28.

Baeti, Nur S., Binadja, Achmad, \& Susilaningsih, E. (2014). Pembelajaran Berbasis Praktikum Bervisi Sets Untuk Meningkatkan Keterampilan Laboratorium dan Penguasaan Kompetensi. Jurnal Inovasi Pendidikan Kimia, 8(1), 1260-1270.

Bire, Arylien, L., Geradus, Uda, \& Bire, J. (2014). Pengaruh Gaya Belajar Visual, Auditorial, dan Kinestetik Terhadap Prestasi Belajar Siswa. Jurnal Kependidikan, 44(2), 168-174.

Dewa, Egidius, Mukin, Maria, U. J., \& Pandango, O. (2020). Pengaruh Pembelajaran Daring Berbantuan Laboratorium Virtual Terhadap Minat dan Hasil Belajar Kognitif Fisika. Jurnal Riset Teknologi dan Inovasi Pendidikan (JARTIKA), 3(2) : 351-359.

Firman, F., \& Rahayu, S. (2020). Pembelajaran Online di Tengah Pandemi Covid-19. Indonesian Journal of Educational Science (IJES), 2(2), 81-89.

Fithriani, Syarifah L., Halim, A., \& Khaldun, I. (2016). Penggunaan Media Simulasi PhET Dengan Pendekatan Inkuiri Terbimbing Untuk Meningkatkan Keterampilan Berpikir Kritis Siswa Pada Pokok Bahasan Kalor Di SMA Negeri 12 Banda Aceh. Jurnal Pendidikan Sains Indonesia, 4(2), 45-52.

Hanifah, N. \& Admoko, S. (2019). Penerapan Model Pembelajaran Argument Driven Inquiry (Adi) Untuk Melatihkan Kemampuan Argumentasi Ilmiah Peserta Didik SMA. Inovasi Pendidikan Fisika, 8(2), 594.

Lidiana, Hamidah, Gunawan, \& Taufik, M. (2018). Pengaruh Model Discovery Learning 
Berbantuan Media PhET Terhadap Hasil Belajar Fisika Peserta Didik Kelas XI SMAN 1 Kediri Tahun Ajaran 2017/2018. Jurnal Pendidikan Fisika dan Teknologi, 4(1), 33-39.

Muakhirin, B. (2014). Peningkatan Hasil Belajar IPA Melalui Pendekatan Pembelajaran Inkuiri Pada Siswa SD. Jurnal Ilmiah Guru “COPE”, 1, 51-57.

Nisa, U.M. (2017). Metode Praktikum untuk Meningkatkan Pemahaman dan Hasil Belajar Siswa Kelas V MI YPPI 1945 Babat pada Materi Zat Tunggal dan Campuran. Proceding Biology Education Conference (62-68). Kalimantan Timur: Universitas Mulawarman.

PhET Tim. (2014). PhET Interactive Simulations. Retrieved from University of Colorado Boulder website: http://phet.colorado.edu.

Prihatiningtyas, S., Prastowo, T., \& Jatmiko, B. (2013). Imlementasi Simulasi PhET dan Kit Sederhana Untuk Mengajarkan Keterampilan Psikomotor Siswa Pada Pokok Bahasan Alat Optik. Jurnal Pendidikan IPA Indonesia, 2(1), 18-22.

Pujiyono, Sudjito, Debora, N., \& Sudarmi, M. (2016). Desain Pembelajaran dengan Menggunakan Media Simulasi PhET (Physics Education And Technology) Pada Materi Medan Listrik. Unnes Physics Education Journal, 5(1), 71-81.

Rahmawati, R.E. (2019). Penerapan Model Pembelajaran Inkuiri Terbimbing Untuk Meningkatkan Kemampuan Berpikir Kritis Tema 5 Subtema 1 Materi Sifat-Sifat Cahaya Pada Siswa Kelas IVA SD Bahrul Ulum Surabaya, Surabaya: Skripsi Pendidikan Guru Madrasah Ibtidaiyah Universitas Islam Negeri Sunan Ampel Surabaya.

Rigianti, H.A. (2020). Kendala Pembelajaran Daring Guru Sekolah Dasar di Kabupaten Banjarnegara. Jurnal Pendidikan dan Pembelajaran Ke-SD-an, 7(2), 297-302.

Rosliani, S.M. (2017). Pengaruh Pemberian Reward and Punishment Terhadap Motivasi Belajar Siswa Kelas X Pada Mata Pelajaran PKN di SMA Pasundan 3 Bandung, Bandung: Skripsi Pendidikan Kewarganegaraan Fakultas Keguruan dan Ilmu Pendidikan Universitas Pasundan.

Saregar, A. (2016). Pembelajaran Pengantar Fisika Kuantum dengan Memanfaatkan Media PhET Simulation dan LKM Melalui Pendekatan Saintifik: Dampak Pada Minat dan Penguasaan Konsep Mahasiswa. Jurnal Ilmiah Pendidikan Fisika Al-BiRuNi, 5(1), 5360.

Sari, D. P., Lutfi, A., \& Qosyim, A. (2013). Uji Coba Pembelajaran IPA Dengan LKS Sebagai Penunjang Media Virtual PhET Untuk Melatih Keterampilan Proses Pada Materi Hukum Archimedes. Jurnal Pendidikan Sains e-Pensa, 1(2), 15-20.

Sinulingga, P., Jhoni T., \& Santoso B. (2016). Implementasi Pembelajaran Fisika Berbantuan Media Simulasi PhET untuk Meningkatkan Hasil Belajar Siswa pada Materi Listrik Dinamis. Jurnal Penelitian dan Pengembangan Fisika, 1(2), 57-64.

Sutarno, et al. (2017). Keterampilan Pemecahan Masalah Mahasiswa dalam Pembelajaran Bandul Fisis Menggunakan Model Problem Solving Virtual Laboratory. Jurnal Pendidikan Fisika dan Teknologi, 3(2): 164-172.

Sylviani, S., Permana, F., C., \& Utomo, R., G. (2020). PhET Simulation Sebagai Alat Bantu Siswa Sekolah Dasar Dalam Proses Belajar Mengajar Mata Pelajaran Matematika. Jurnal Pendidikan Multimedia, 2(1), 1-10. 
Wakhidah, Nur. (2016). Analisis Kesulitan Mengajar Guru Kelas Pada Mata Pelajaran IPA di MI Islamiyah Sidoarjo. Journal of Islamic Elementary School (JIES) UIN Surabaya, $1(2)$.

Wakhidah, N. (2018). Pembelajaran dengan Pendekatan Saintifik Terhadap Kemampuan Berpikir Kritis Mahasiswa Calon Guru Madrasah Ibtidaiyah. Premiere Educandum: Jurnal Pendidikan Dasar dan Pembelajaran, 8(1), 152-153.

Yusran, Tandililing, E., \& Hamdani. (2017). Remediasi Miskonsepsi Siswa Menggunakan Strategi Konflik Kognitif Berbantuan Simulasi PhET Tentang Rangkaian Listrik di SMA. Jurnal Pendidikan dan Pembelajaran Untan, 1-13. 